\title{
Leitão, Ema Sofia (2003). Desenhos Animados. Discursos sobre Ser Criança.
} Lisboa: Edições 70.

Sara Pereira

Este livro de Ema Sofia Leitão, baseado na tese de doutoramento que a autora desenvolveu na Universidade de Cardiff, Reino Unido, constitui um excelente contributo para os estudos das crianças e da televisão. $\mathrm{Na}$ verdade, é uma referência imprescindível e obrigatória para todos os que investigam neste domínio mas também para pais, profissionais de educação e outros adultos que trabalham com os mais pequenos. É também uma obra que vem reforçar um campo ainda insuficientemente estudado em Portugal, sendo, por isso, motivo de regozijo para os poucos investigadores que se dedicam, no nosso país, ao estudo das crianças e dos media.

Tratando-se de um trabalho académico, a obra organiza-se em sete capítulos, uns dedicados à revisão da literatura, outro à explicitação da metodologia de investigação e os seguintes, à apresentação, análise e discussão dos dados do estudo empírico. Especificamente, o estudo desenvolvido teve como principal objectivo analisar os programas de animação em formato televisivo. A autora efectuou uma análise a três níveis: a) auscultação da perspectiva dos criativos sobre a animação para públicos infantis; b) análise dos conteúdos dos textos (programas), numa perspectiva semiótica, para compreender como os públicos infantis são abordados; c) auscultação das perspectivas das crianças para conhecer as suas leituras acerca dos programas de animação e a forma como os usam para construírem as suas identidades sociais. Neste ponto, a autora faz também o cruzamento das leituras das crianças com as leituras pretendidas pelos criativos.

$\mathrm{Na}$ primeira parte do livro a autora apresenta uma interessante reflexão acerca das construções da infância baseando-se, para tal, em abordagens teóricas de referência, nomeadamente a sociologia da infância. A autora debruça-se, em particular, sobre a construção dos públicos infantis, reconhecendo, com base nas perspectivas de autores de reconhecido mérito, como David Buckingham, as competências das crianças face aos conteúdos mediáticos. Baseando-se no 'paradigma da competência social', Ema Leitão refere a necessidade e a importância de se considerar as experiências e as circunstâncias dos quotidianos das crianças para melhor se compreender a acção social das mesmas. Os vários estudos referenciados pela autora permitem, como ela própria refere, "desmistificar a construção da criança como espectadora passiva, demonstrando as suas capacidades discursivas reveladoras de gostos e preferências, mas também da forma como constroem as suas identidades influenciadas pelas dinâmicas sociais (p. 67). É neste seguimento que a autora debate os usos da televisão por crianças para depois abordar os aspectos cognitivos e de desenvolvimento na construção de sentidos no acto de ver televisão. 
A segunda parte da obra abre com uma abordagem ao texto animado como comunicação. A autora apresenta o modelo que irá fundamentar a sua análise dos programas de animação. Buscando um modelo que lhe permita analisar a produção dos programas de animação, o programa enquanto texto e os públicos que o recebem, a autora recorre aos estudos da comunicação, em particular aos contributos da semiótica, para sustentar o modelo de análise.

Antes de partir para a explicitação das estratégias de investigação, Ema Leitão faz uma importante abordagem aos filmes de animação para crianças, analisando as influências do processo de globalização na produção e distribuição da animação para os públicos infantis, reflectindo também sobre a influência deste fenómeno nas questões de identidade. Defendendo a ideia de que a globalização "não é simplesmente uma forma de imperialismo cultural" mas "um meio para a circulação de múltiplos discursos culturais numa escala mundial desde que seja respeitada a diversidade dos conteúdos" (p. 125), a autora conclui, no entanto, que "os conteúdos são determinados não por um conhecimento aprofundado dos públicos, mas por conhecimentos técnicos e artísticos e pela necessidade de sobrevivência no mercado global. A televisão transnacional resulta de um mercado dominado por grandes grupos multinacionais capazes de ofertas relativamente baratas que originam a diminuição do investimento na produção nacional e condicionam as preferências dos públicos” (p. 238).

Após o capítulo metodológico, de particular interesse para quem desenvolve investigação nesta área, surge a análise dos quatro programas de animação seleccionados: Pokemon e Sailomoon (As Navegantes da Lua), ambas as séries de origem japonesa; The Tale of the Three Sisters Who Fell into the Mountain (O Conto das Três Irmãs que Caíram na Montanha), episódio integrante da co-produção internacional The Animated Tales of the World (ATW); e um episódio da série de produção portuguesa A Maravilhosa Expedição às Ilhas Encantadas. Neste capítulo a autora explora também o conceito de 'especificidade cultural', e a forma como emerge nos desenhos animados analisados, concluindo que “a especificidade cultural da animação da televisão está condicionada pela consideração dos potenciais compradores e pelo conhecimento profissional da economia especifica do mercado, não resultando necessariamente de um profundo conhecimento do público-alvo" (p. 191). Ema Leitão conclui ainda que as várias construções da infância presentes nos programas de animação se caracterizam mais pelas semelhanças do que pelas diferenças. Como refere a autora: "mais do que a diferença, é a semelhança o aspecto marcante da forma como os criativos da animação constroem os públicos infantis" (p. 191). Face a este cenário, a investigadora levanta uma importante questão: "haverá, então, uma impossibilidade da prevalência da especificidade cultural no mercado global?” (p. 192). Após a análise dos programas referidos, a autora afirma que "mesmo num contexto de globalização é possível conferir um certo grau de especificidade a um desenho animado, adaptando a linguagem ao contexto sociocultural de recepção". Esta adaptação ao contexto cultural local pode ser conseguida, como se sugere num estudo sobre a televisão para crianças em Portugal (Pereira, 2006) ${ }^{1}$,

\footnotetext{
${ }^{1}$ Pereira, S. (2006). Por Detrás do Ecrã. Televisão para Crianças em Portugal. Porto: Porto Editora.
} 
através, por exemplo, de uma dobragem de qualidade, que se preocupe em introduzir no programa em causa as marcas da cultura do país em que o mesmo vai ser exibido.

No último capítulo surgem então as perspectivas dos públicos infantis. Participaram no estudo crianças com idades compreendidas entre os sete e os nove anos, idades correspondentes à frequência do $1 .^{\circ}$ Ciclo do Ensino Básico. As suas perspectivas acerca das séries de animação anteriormente referidas foram recolhidas através do inquérito por questionário, da entrevista de grupo, da produção de desenhos sobre o programa que as crianças gostariam de criar e do visionamento e comentário a dois episódios de séries 'não comerciais', um da série O Conto das Três Irmãs que Caíram na Montanha e outro de A Maravilhosa Expedição às Ilhas Encantadas. A autora encontrou, nas crianças que participaram no estudo, um público crítico e criativo, com um relacionamento activo com os textos televisivos. Tal como outros autores que evidenciaram a capacidade dos mais novos para 'glocalizar' os conteúdos dos programas televisivos que lhes são dirigidos (cf. Pereira, 2006) ${ }^{2}$, Ema Leitão encontrou naquelas crianças "uma capacidade de adaptar produtos globais, pelo recurso a referências aos seus contextos sociais e culturais" (p. 236). Desta parte do seu trabalho fica também a mensagem da importância de se dar o salto da mera idealização dos públicos infantis para o seu conhecimento aprofundado, no sentido de se melhorar a comunicação entre criadores, produtores, programadores e públicos.

\footnotetext{
${ }^{2}$ Pereira, S. (2006). 'A Minha TVé um Mundo'. Programação para Crianças na Era do Ecrã Global. Porto: Campo das Letras.
} 